\title{
Desain Landing Craft Utility (LCU) Guna Menunjang Program Pemerataan Pembangunan Di Daerah Tertinggal, Studi Kasus: Sungai Ketingan, Sidoarjo
}

\author{
Esna Tri Nurdiyanto, dan Hesty Anita Kurniawati \\ Departemen Teknik Perkapalan, Fakultas Teknologi Kelautan, Institut Teknologi Sepuluh \\ Nopember (ITS) \\ e-mail:tita@na.its.ac.id
}

\begin{abstract}
Abstrak-Pemerintah Indonesia melalui Kementrian Desa, Pembanguan Daerah Tertinggal dan Transmigrasi mengsahkan Peraturan Menteri Desa, Pembanguan Daerah Tertinggal dan Transmigrasi No. 21 Tahun 2015 tentang penetapan prioritas pembangunan di daerah tertinggal sebagai bukti keseriusan untuk mensuseskan program pemerataan pembangunan yang dicanangkan presiden terpilih. Di Kecamatan Sidoarjo di mana merupakan daerah penyangga kota metropolitan Surabaya terdapat daerah terpencil bernama Desa Ketingan yang pembangunannya jauh tertinggal dari desa lainnya di Kecamatan Sidoarjo. Bantuan yang disalurkan oleh pemerintah terkendala belum adanya jalur darat dan belum memadainya sarana angkutan jalur sungai yang menjadi akses utama menuju desa tersebut. LCU Ketingan 01 adalah suatu gagasan desain kapal penumpang serta barang sebagai solusi untuk membantu mobilitas warga serta mendistribusikan bantuan dari pemerintah dalam rangka program pemerataan pembangunan yang ada di daerah Sungai Ketingan, Sidoarjo. Kapal ini akan beroperasi dari dermaga Desa Ketingan sampai dermaga Depo Ikan di Desa Bluru Timur, Jl. Lingkar Timur Kabupaten Sidoarjo sepanjang 10 KM. Waktu yang dibutuhkan kapal ini dalam sekali trip 62 menit. Dalam menentukan ukuran utama, kapal ini menggunakan metode sesuai dengan kapasitas muatan yang akan dibawa dan juga menyesuaikan dengan keadaan sungai. Selanjutnya dilakukan pembuatan layout awal untuk melakukan analisis teknis seperti displasmen, berat kapal, stabilitas dan perhitungan freeboard. Akhirnya didapatkan desain kapal LCU dengan payload 30 orang, muatan barang maksimal 3 ton beserta $3 \mathrm{kru}$. Ukuran utama yang didapatkan adalah $\mathrm{Lpp}=17 \mathrm{~m} ; \mathrm{B}=$ $3.5 \mathrm{~m} ; \mathrm{H}=1.2 \mathrm{~m} ; \mathrm{T}=0.75 \mathrm{~m}$. Tinggi freeboard minimum sebesar $0.45 \mathrm{~m}$, dan kondisi stabilitas Kapal Motor Penyeberangan memenuhi kriteria Intact Stability (IS) Code Reg. III/3.1. Setelah itu dilakukan analisis ekonomis sehingga didapatkan harga LCU sebesar Rp727,333,887.07
\end{abstract}

Kata Kunci-Landing Craft Utility (LCU), Pemerataan Pembangunan, Sungai Ketingan, Sidoarjo.

\section{PENDAHULUAN}

$\mathrm{P}$ EMERINTAH berkomitmen untuk mewujudkan pemerataan pembangunan. Deputi Pembiayaan Pembangunan Bappenas Wismana mengatakan, sejak era Pemerintahan Joko Widodo, pemerintah tak hanya menilai pertumbuhan namun pemerataan juga penting. "Oleh karena itu, sejak era Jokowi gini ratio menjadi salah satu target fiskal," kata Wismana dalam keterangan pers di Jakarta [1]. Fokus pemerataan tersebut pada pembangunan jalan desa serta pembangunan talut pada saluran irigasi sesuai dengan Peraturan Menteri Desa Pembangunan Daerah Tertinggal dan Transmigrasi Nomor 21 Tahun 2015 [2].

Di Kecamatan Sidoarjo, Kabupaten Sidoarjo, Jawa Timur, terdapat wilayah terpencil bernama Desa Ketingan. Desa Ketingan masuk wilayah Kecamatan Sidoarjo Kota. Tetapi kampung tambak ini paling terisolasi di Kabupaten Sidoarjo. Akses jalan darat sulit, apalagi musim hujan. Karena akses menuju desa ketingan sulit maka pembangunan di daerah ini paling tertinggal jika dibandingkan dengan desa lain di wilayah Sidoarjo. Di desa ini kondisi bangunan sekolahnya rusak dan perlu perhatian dari pemerintah kabupaten setempat. Kepala Dinas Pendidikan Kabupaten Sidoarjo, Mustain Baladan, Sabtu mengatakan sekolah ini sebenarnya mendapatkan jatah renovasi tahun 2014, namun diakui renovasi itu masih sangat terbatas terkendala sulitnya akses menuju lokasi. Selain itu masyarakat Desa Kepetingan yang ingin membangun atau merenovasi rumahnnya terkendala belum adanya akses jalan darat yang memadai dan akses melalui jalur sungai terkendala mahalnya biaya angkut material bangunan yang dapat mencapai satu juta rupiah untuk sekali pengangkutan material [3].

Menyikapi permasalahan seperti yang disebutkan di atas, penulis mempunyai ide dan wacana yang dituangkan dalam Studi ini yaitu untuk membuat suatu desain kapal LCU (Landing Craft Utility) yang nantinya sesuai ukuran kapal yang bisa dioperasikan dan dapat memberikan layanan transportasi serta untuk menunjang program pemerataan pembangunan daerah tertinggal khususnya di Desa Kepetingan Sidoarjo. 


\section{TINJAUAN PUSTAKA}

\section{A. Desa Ketingan}

Desa Ketingan merupakan salah satu bagian dari dusun yang terdapat di Desa Sawohan, yang mana Sawohan ini berada di dalam cakupan wilayah Kecamatan Buduran Kabupaten Sidoarjo. Adapun batas wilayah Dusun Kepetingan di sebelah selatan berbatasan dengan Dusun Bromo Desa Balongdowo Kecamatan Candi, di sebelah barat berbatasan dengan Desa Bluru Kecamatan Sidoarjo, di sebelah timur berbatasan dengan Dusun Pucukan Desa Gebang Kecamatan Sidoarjo, dan di sebelah utara berbatasan dengan Desa Karanggayam Kecamatan Sidoarjo.

Desa Ketingan dapat dijangkau dengan melalui dua jalur, yakni: jalur darat dan jalur air. Akan tetapi jalur darat hanya bisa ditempuh ketika musim kemarau saja. Hal ini di karenakan jalan menuju Desa Ketingan hanya bisa di lewati melalui pematang tambak yang lebarnya kurang lebih hanya $30 \mathrm{~cm}$.

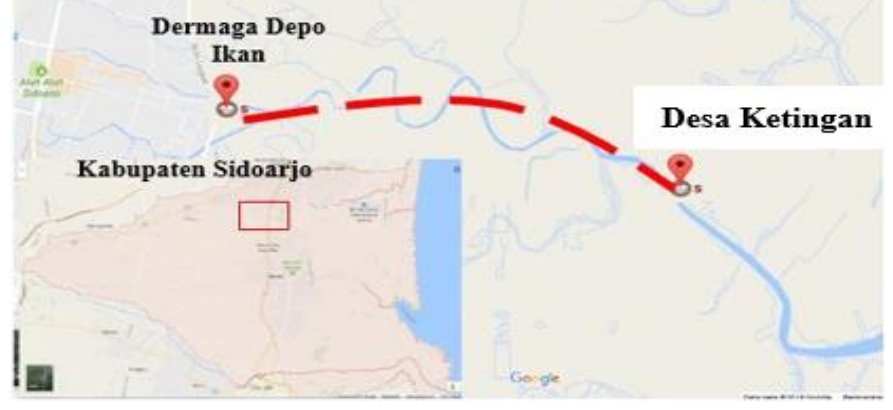

Gambar 1. Lokasi Desa Ketingan

Selain itu di jalan menuju Dusun Ketingan tidak di dapati arah petunjuk jalan, sehingga apabila baru pertama kali menuju Dusun Kepetingan, tanpa di damping warga Dusun tersebut kemungkinan tersesat ke desa lain sangat besar. Waktu yang ditempuh melalui jalan darat sekitar 60-90 menit dengan kecepatan rata-rata $15 \mathrm{~km} / \mathrm{jam}$, sedangkan jika ditempuh melalui jalur air dengan menggunakan perahu motor (warga Dusun sekitar menyebutnya "Barito") memakan waktu sekitar 45-60 menit, dengan ongkos Rp.500.000,00/Barito pulang-pergi [4].

\section{B. Batasan Kondisi Sungai}

Seiring semakin tingginya kebutuhan akan sarana transportasi, saat ini kapal tidak hanya dioperasikan pada daerah pelayaran laut saja, melainkan digunakan pula untuk beroperasi di perairan sungai. Akan tetapi, untuk kapal yang beroperasi di perairan sungai, terdapat batasan perairan yang perlu diperhatikan mengingat sungai memiliki dimensi ukuran yang terbatas. Dimensi sungai sangatlah berpengaruh terhadap penentuan ukuran utama kapal, seperti lebar kapal dibatasi oleh lebar sungai, sarat kapal dibatasi oleh kedalaman sungai. [5]

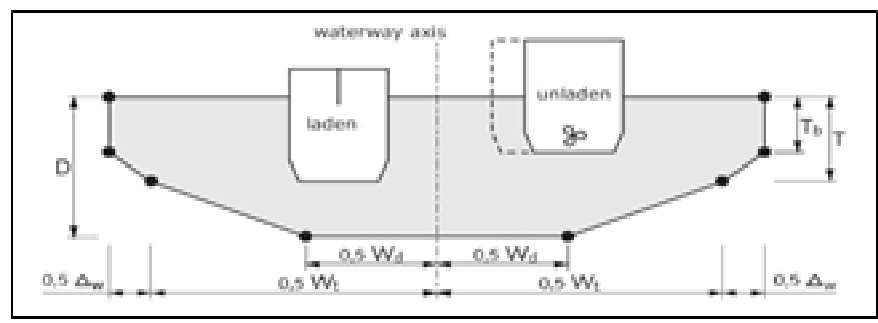

Gambar 2. Ukuran Penampang Melintang Sungai

Dalam mendesain kapal sebagai sarana transportasi sungai hal utama yang harus diperhatikan adalah kondisi teknis ukuran sungai yang dapat membatasi ukuran utama dari kapal yang akan melintasinya, diantaranya adalah kedalaman sungai, lebar sungai, dan ketinggian jembatan.. Batasan dimensi sungai dibedakan menjadi tiga berdasarkan jenis penggunaan jalur pelayaran kapal. Berikut merupakan batasan ukuran sungai sesuai dengan jenis pelayarannya yang dapat dilihat pada Tabel 1 sebagai berikut:

Tabel 1.

Batasan Dimensi Sungai Sesuai Penggunaan Jalur

\begin{tabular}{ccccc}
\hline \hline $\begin{array}{c}\text { Jalur } \\
\text { Pelayanan }\end{array}$ & $\mathrm{W}_{\mathrm{d}}$ & $\mathrm{W}_{\mathrm{t}}$ & $\underline{\Lambda}_{\mathrm{W}}$ & $\mathrm{D}$ \\
\hline $\begin{array}{c}\text { Two-line } \\
\text { Normal } \\
\text { Two-line } \\
\text { Narrow }\end{array}$ & $2 \times \mathrm{B}_{\max }$ & $4 \times \mathrm{B}_{\max }$ & $0.05 \times \mathrm{L}$ & $1.2 \times \mathrm{T}_{\max }$ \\
Single-line & $\mathrm{B}_{\max }$ & $3 \times \mathrm{B}_{\max }$ & $0.05 \times \mathrm{L}$ & $1.2 \times \mathrm{T}_{\max }$ \\
\hline
\end{tabular}

\section{METEDOLOGI PENELITIAN}

\section{A. Diagram Alir}

Tahapan dari metodologi penelitian yang digunakan digambarkan pada diagram alir pada Gambar 3:

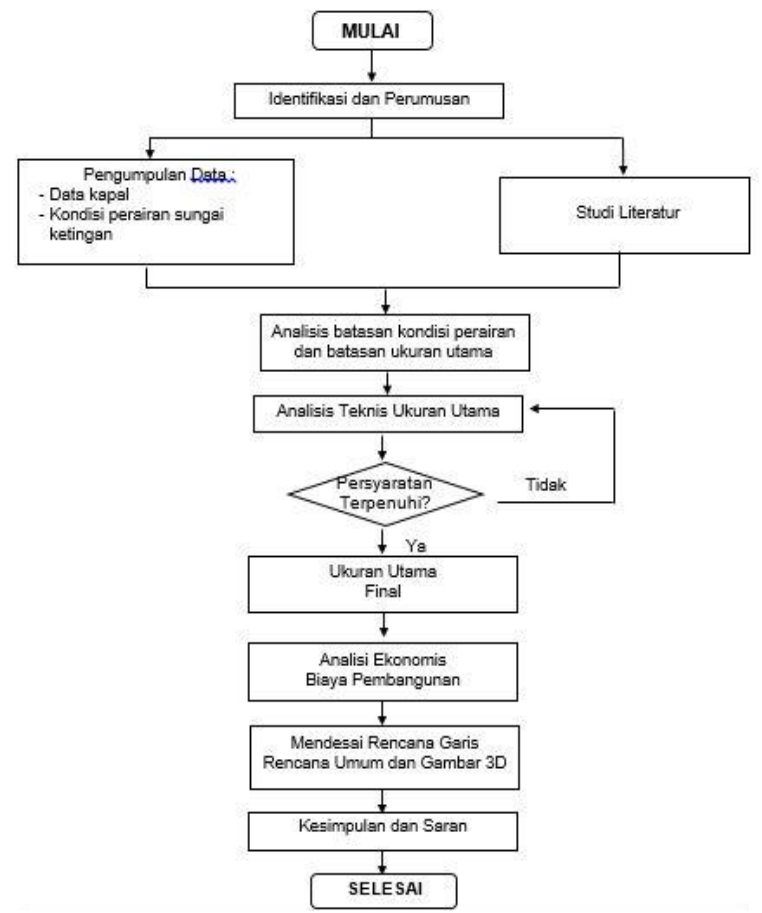

Gambar 3. Diagram Alir Motodologi Penelitian 


\section{ANALISIS TEKNIS}

\section{A. Penentuan Payload}

Penentuan payload kapal landing craft utility ini berdasarkan hasil survei jumlah penduduk di Desa Ketingan, Sidoarjo dan intensitas bepergian warga dalam rentang satu minggu dengan cara melakukan survei langsung. Survei langsung yang dilakukan yaitu dengan kuesioner untuk mengetahui antusias masyarakat jika diadakan jasa angkutan kapal. Penentuan sampel menurut Gay dan Diehl (1992), jika penelitiannya bersifat deskriptif maka sampel minimumnya adalah 10\% dari populasi. Di Desa Ketingan terdapat 105 Kepala Keluarga dengan asusmsi 4 anggota keluarga tiap kepala keluarga maka jumlah populasi sebanyak 420 orang. Jadi minimal banyaknya sampel adalah 42 orang. Berikut adalah rekapitulasi hasil survei ditunjukkan pada Tabel 2.

Tabel 2.

Hasil Survei

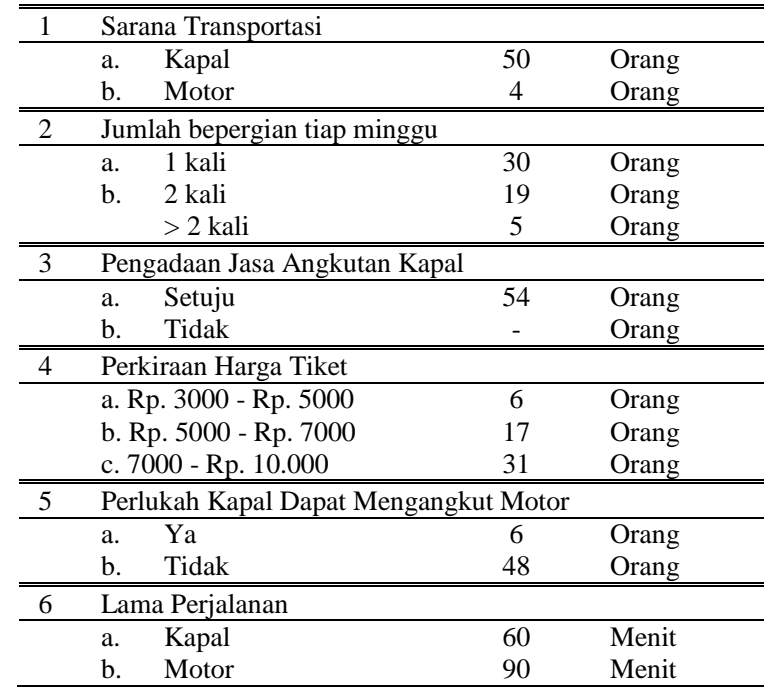

Kemudian diasumsikan dalam setiap minggu kapal melakukan trip sebanyak 7 kali, maka kapasitas kapal per tripnya adalah:

Kapasitas $=210 / 7=30$ penumpang.

Direncanakan bagasi penumpang sebesar $50 \mathrm{~kg} /$ penumpang dan muatan cargo sebesar 1.5 ton sehingga berat payload + bagasi dan cargo sebesar 5.1 ton.

\section{B. Layout Awal}

Dalam mendesain sebuah kapal, diperlukan layout awal pada kapal untuk menunjukkan gambaran umum mengenai desain yang akan dibentuk. Dari survey lapangan di dapatkan luasan geladak yang dibutuhkan untuk membuat desain awal Landing Craft Utility.

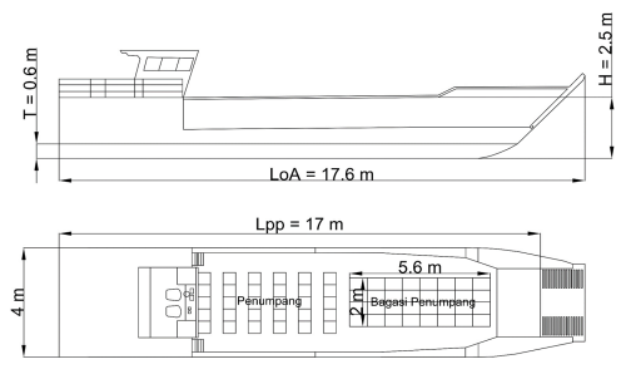

Gambar 4. Layout Awal LCU

\section{Perhitungan Awal}

Dari layout awal kemudian dihitung perhitungan perhitungan awal yang terdiri dari:

1) Perbandingan ukuran kapal

2) Froude Number

3) Koefisien Blok

4) Koefisien midship

5) Koefisien prismatic

6) Koefisien waterplan

7) Longitudinal Center of Bouyency

8) Displasement

\section{Hambatan}

LCU yang didesain ini menggunakan bantuan software maxsurf resistance, dan didapatkan hambatan total sesesar $1.570 \mathrm{kN}$ serta didapatkan power mesin sebesar $3.950 \mathrm{~kW}$.

\section{E. LWT (Leight Weight Tonnage)}

LWT merupakan berat kapal kosong yang terdiri dari berat baja, berat perlengkapan, dan berat permesinan kapal.. Dari hasil perhitungan didapatkan harga LWT sebesar 24.310 ton.

\section{F. DWT (Dead Weight Tonnage)}

DWT merupakan berat mati kapal yaitu muatan maksimum yang dapat diangkut. Yang termasuk dalam perhitungan DWT adalah total dari berat muatan, kru dan barang bawaan, berat consumable dan payload. Dari hasil perhitungan didapat harga DWT sebesar 7.350 ton.

\section{G. Freeboard}

Perhitungan freeboard standar mengacu pada Peraturan Standar Kapal Non Konvensi Berbendera Indonesia. Dalam menghitung freeboard terdapat beberapa koreksi yang perlu dilakukan antara lain koreksi terhadap $\mathrm{Cb}$, koreksi terhadap tinggi kapal, dan koreksi terhadap bangunan atas. Harga freeboard kapal sebesar $0.55 \mathrm{~m}$ sedangkan harga freeboard minimum sebesar 0.46 sehingga freeboard desain telah memenuhi peraturan.

\section{H. Stabilitas}

Stabilitas merupakan salah satu kriteria yang harus dipenuhi pada proses desain kapal. Analisis stabilitas digunakan untuk mengetahui keseimbangan kapal secara melintang (kondisi oleng) pada beberapa kriteria kondisi pemuatan (loadcase). Pada perhitungan stabilitas ini dilakukan dengan menggunakan software Maxsurf Educational Version. Kriteria stabilitas yang digunakan adalah kriteria stabilitas untuk kapal jenis umum dan kapal penumpang yang mengacu pada Intact Stability (IS) Code Reg. III/3.1. design criteria applicable to all ship dengan kriteria loadcase sebagai berikut:

1. Loadcase I : muatan 100\% dan consummable $100 \%$

2. Loadcase II : muatan $100 \%$ dan consummable $50 \%$

3. Loadcase III : muatan 100\% dan consummable $10 \%$

4. Loadcase IV : muatan $70 \%$ dan consummable $100 \%$

5. Loadcase V : muatan $70 \%$ dan consummable $50 \%$

6. Loadcase VI : muatan $70 \%$ dan dan consummable $10 \%$ Berikut adalah rekapitulasi hasil running setelah dilakukannya pemuatan dalam setiap kondisi/loadcase: 
Tabel 3.

Rekapitulasi Satbilitas

\begin{tabular}{cccccccc}
\hline \hline \multirow{2}{*}{ No } & \multirow{2}{*}{ Kriteria } & \multicolumn{7}{c}{ Loadcase } \\
\cline { 3 - 8 } & & 1 & 2 & 3 & 4 & 5 & 6 \\
\hline 1. & $\mathrm{e}_{0-30}=3.15$ & 12.89 & 12.85 & 12.73 & 12.96 & 13.56 & 14.1 \\
2. & $\mathrm{e}_{30-40}=5.15$ & 8.87 & 8.78 & 9.33 & 8.91 & 9.26 & 1.72 \\
3. & $\mathrm{GZ}_{30}=0.2$ & 0.946 & 0.932 & 0.997 & 0.947 & 0.99 & 1.028 \\
4. & $\Theta_{\mathrm{Max}}=25^{0}$ & 48.2 & 46.8 & 48.2 & 47.7 & 48.2 & 48.6 \\
5. & $\mathrm{GM}^{0}=0.15$ & 1.637 & 1.653 & 1.729 & 1.649 & 1.746 & 1.852 \\
& $\mathrm{Status}$ & Pass & Pass & Pass & Pass & Pass & Pass \\
\hline
\end{tabular}

I. Trim

Trim merupakan kondisi keseimbangan kapal secara memanjang. Trim terjadi karena adanyan perbedaan titik berat kapal keseluruhan secara memanjang tidak sama dengan titik berat kapal yang tercelup air, sehingga menyebabkan perbedaan sarat pada bagian depan dan belakang kapal. Pemeriksaan trim ini dilakukan dengan menggunakan software Maxsurf Educational Version. Dengan mengacu pada SOLAS Reg. II/7, dimana kondisi trim maksimum yang diperbolehkan adalah $0.5 \%$ Lwl. Berikut adala adalah hasil running yang dilakukakn untuk melihat hasil trim disetiap loadcase:

Tabel 4.

Rekapitulasi Trim

\begin{tabular}{lcccccc}
\hline \hline & \multicolumn{6}{c}{ Loadcase } \\
\cline { 2 - 7 } & 1 & 2 & 3 & 4 & 5 & 6 \\
\hline deg & -0.047 & -0.32 & -0.53 & 0.01 & -0.26 & -0.47 \\
$\mathrm{~m}$ & -0.002 & -0.015 & -0.025 & 0.00 & -0.01 & -0.22 \\
Trim & Buritan & Buritan & Buritan & Halauan & Buritan & Buritan \\
Krit & \multicolumn{2}{c}{$\Theta_{\text {Max }}>25^{0}$} & deg & 48.2 & 46.8 & \\
eria & & Pass & Pass & Pass & Pass & Pass \\
\hline
\end{tabular}

\section{J. Lines Plan, General Arragement, Safety Plan}

Lines Plan merupakan gambaran bentuk lambung kapal yang diproyeksikan menjadi tiga sudut pandang yaitu sudut pandang depan, samping, dan atas. Pembuatan lines plan menggunakan bantuan software Maxsurf Modeler Educational Version dan CAD Untuk mendapatkan kriteria displasemen yang sesuai dengan perhitungan dilakukan editing manual dengan menggeser control point.

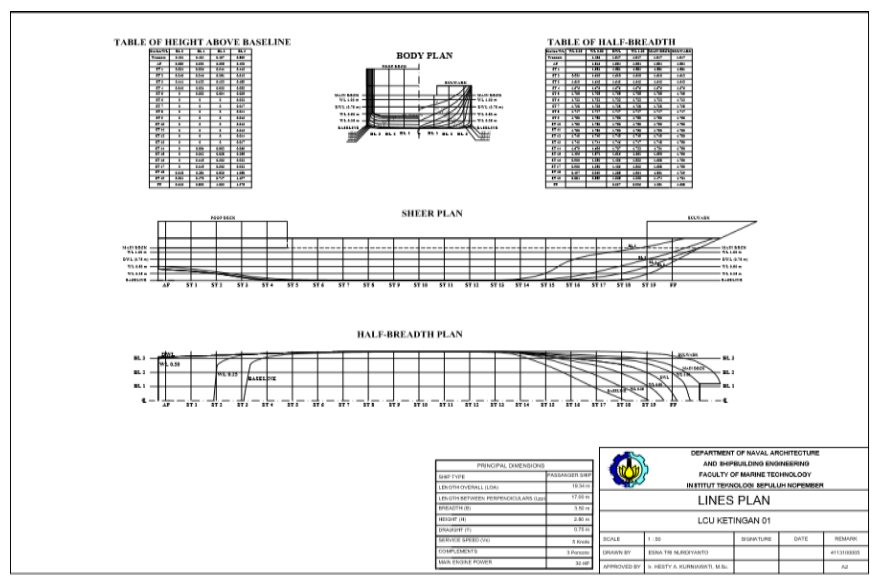

Gambar 5. Lines Plan

General Arragement merupakan perencanaan ruangan di dalam kapal yang dibutuhkan sesuai dengan fungsi dan perlengkapan kapal. General Arragement dibuat menyesuaikan dengan rencana garis yang telah dibuat. Pada pembuatan general arragement untuk kapal jenis ini disesuaikan dengan perlengkapan yang dibutuhkan dengan fasilitas dermaga yang telah ada. Secara umum general arragement digambarkan dalam tiga sudut pandang yaitu tampak depan, tampak samping, dan tampak atas kapal.

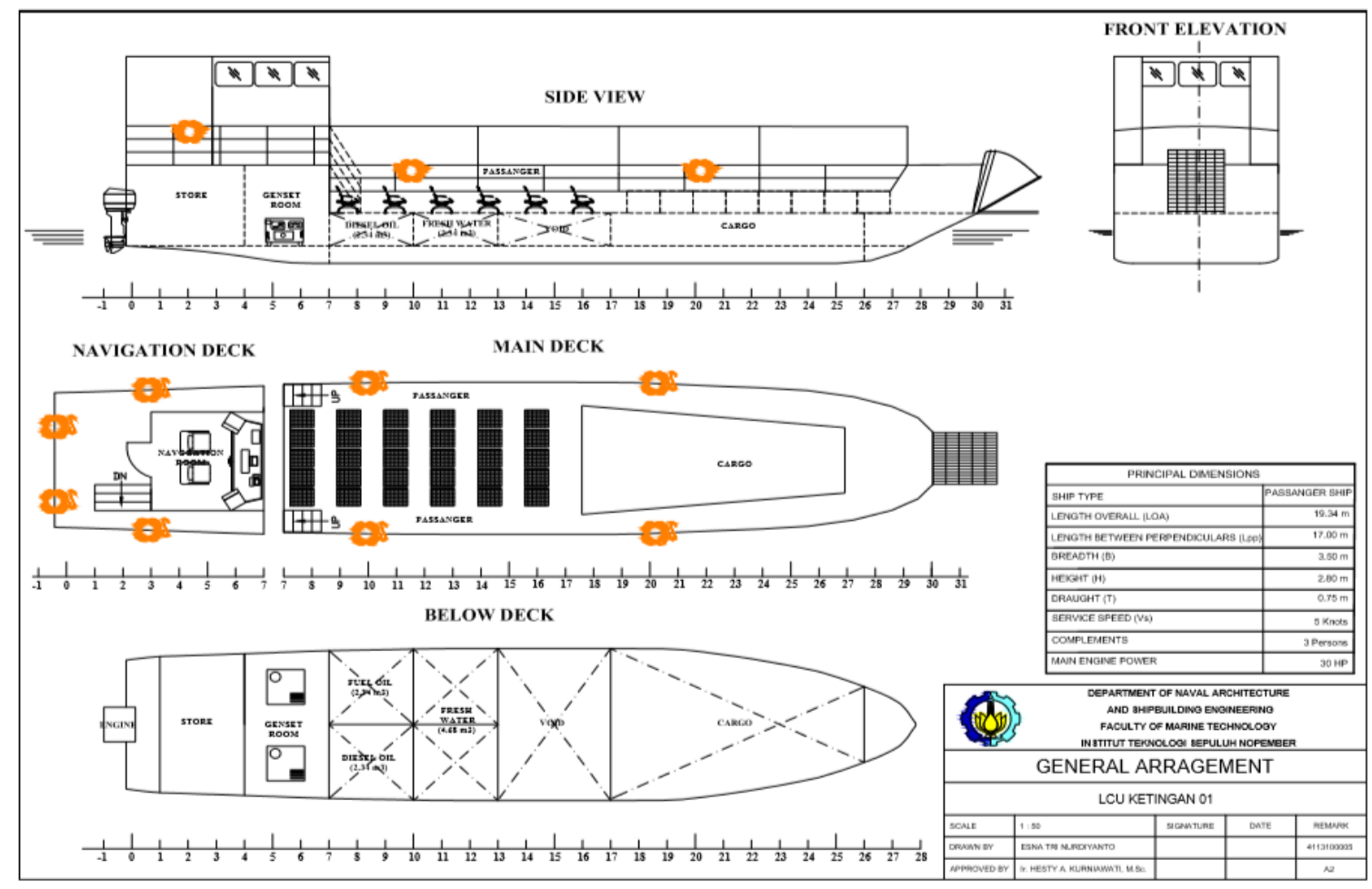

Gambar 6. General Arragement 


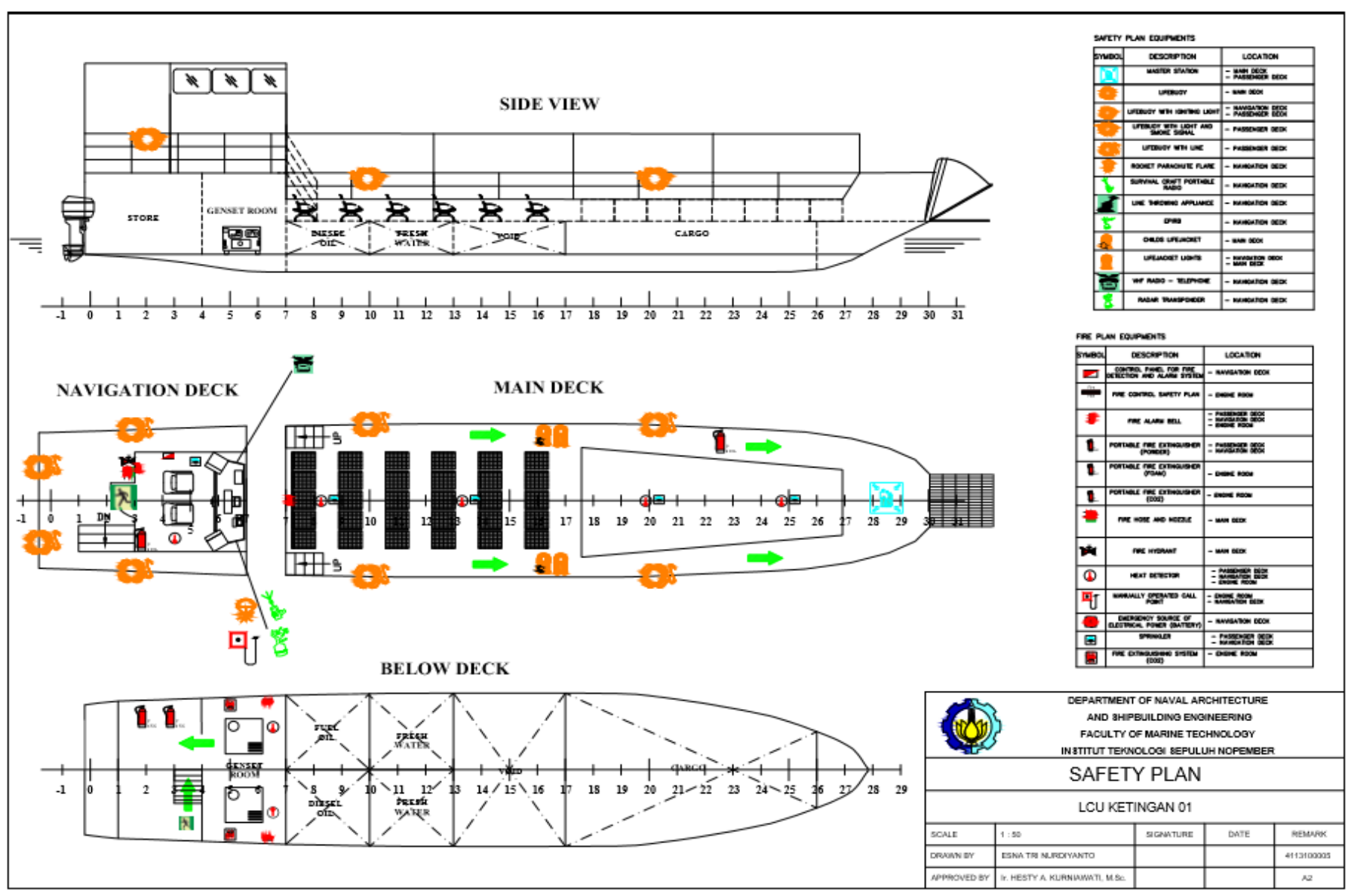

Gambar 7. Safety Plan

Safety plan adalah perencanaan alat-alat keselamatan, komunikasi, dan navigasi pada kapal. Perencanaan mengacu regulasi pada SOLAS 1974. Peletakan peralatan harus berdekatan dengan tempat yang membutuhkan alat tersebut. [6]

\section{K. 3D Model}

Pembuatan model kapal ini harus sesuai dengan ukuran utama kapal dengan bentuk lambung yang menyerupai kapal kapal tersebut. Banyak aplikasi yang digunakan dalam membuat model 3 dimensi dari kapal yang telah didesain.

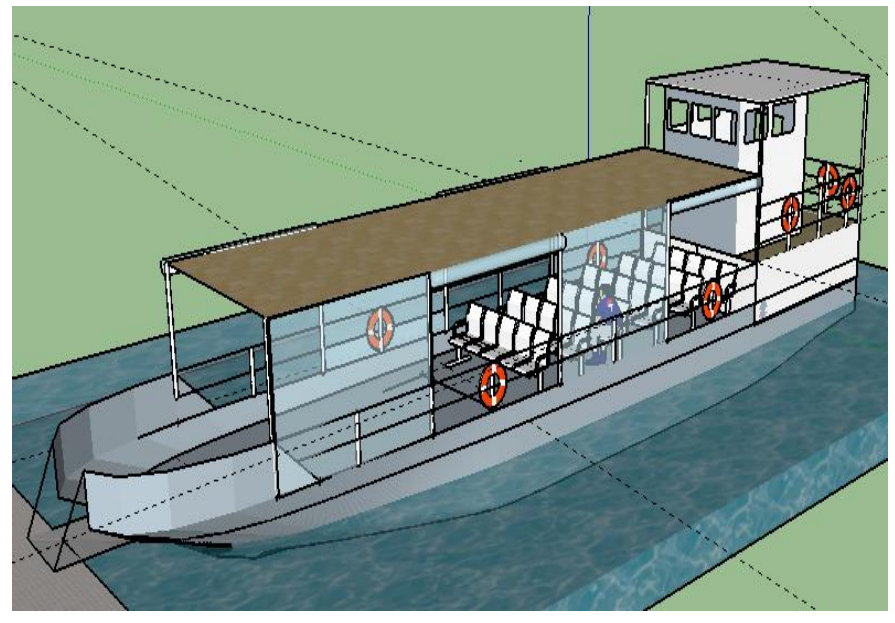

Gambar 8. 3D Model Tampak Samping

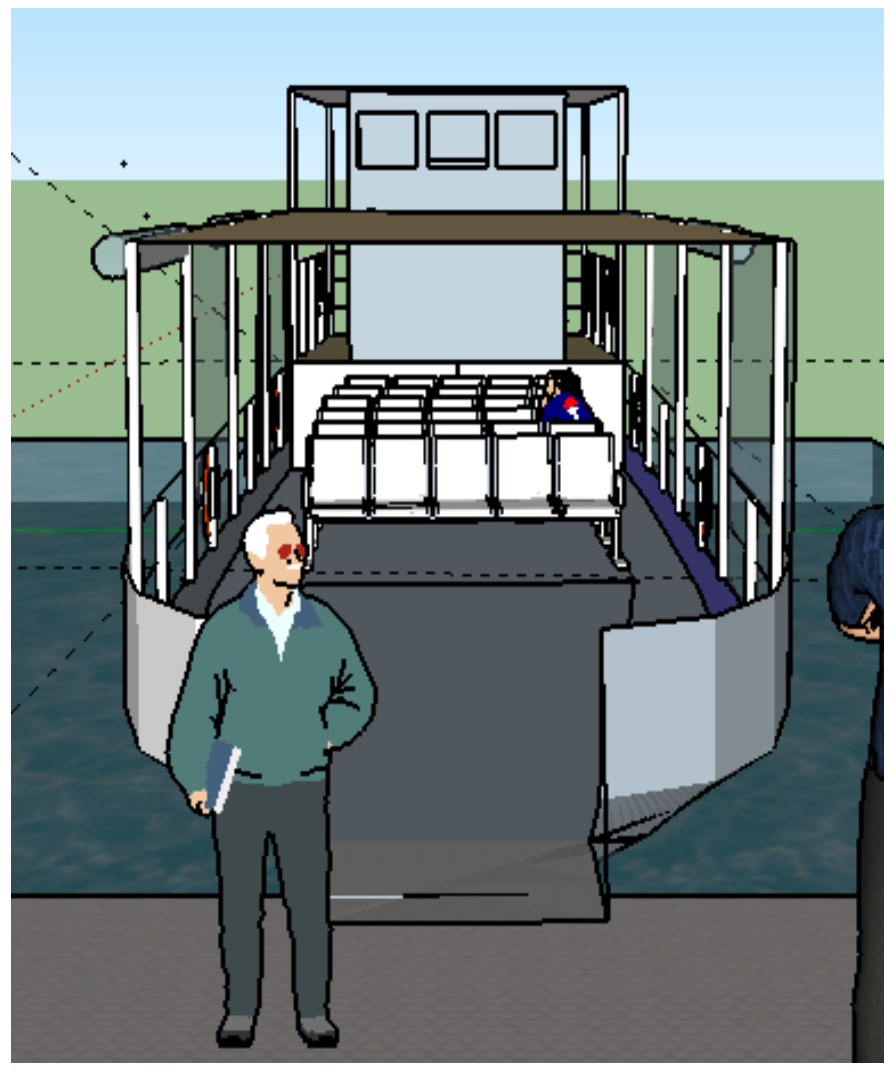

Gambar 9. 3D Model Tampak Depan 


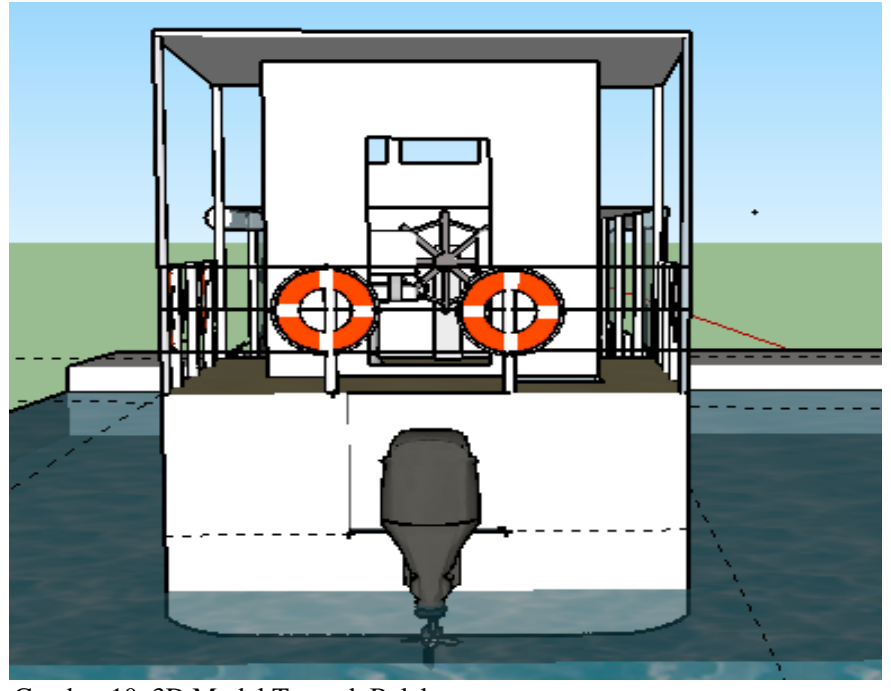

Gambar 10. 3D Model Tampak Belakang

\section{ANALISIS EKONOMIS}

Dalam perhitungan analisis ekonomis dilakukan perhitungan biaya pembangunan, biaya operasional serta kelayakan investasi dan perhitungan Break Event Point.

\section{A. Biaya Pembangunan}

Biaya pembangunan kapal terdiri dari beberapa komponen, yaitu biaya baja kapal, biaya peralatan, biaya motor penggerak kapal, serta biaya komponen kelistrikan. Besar biaya pembangunan kapal adalah Rp 512,206,963. Kemudian untuk menentukan harga jual kapal (price), maka harga pokok produksi selajutnya dikoreksi terhadap keuntungan galangan, pajak, dan inflasi sehingga didapat harga kapal sebesar $\mathrm{Rp}$ 727,333,887.07.

\section{B. Biaya Operasional}

Besar biaya operasional setiap tahunnya adalah $\mathrm{Rp}$ 405,597,820/tahun.

\section{Kelayakan Investasi}

Perhitungan kelayakan investasi ini meliputi beberapa aspek seperti perhitungan NPVdan BEP. Didapatkan besar nilai

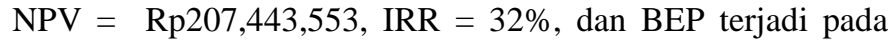
tahun ke 4 serta harga tiket $=\operatorname{Rp} 3,500$.

\section{KESIMPULAN DAN SARAN}

\section{A. Kesimpulan}

Pada jurnal ilmiah ini dilakukan analisis secara teknis dan ekonomis pada LCU Ketingan 01. Berdasarkan hasil analisis yang telah dilakukan dapat disimpulkan bahwa LCU ini memenuhi dari aspek teknis maupun ekonomis dan diambil kesimpulan sebagai berikut:

1. Desain LCU yang sesuai dengan karakteristik Sungai Ketingan, Sidoarjo. Didapatkan Ukuran utama LCU Ketingan 01, yaitu:

- Panjang (L) : $17 \mathrm{~m}$

- Lebar (B) : $3.50 \mathrm{~m}$

- Tinggi (D) : $1.2 \mathrm{~m}$

- Sarat (T) $\quad 0.75 \mathrm{~m}$
LCU ini bisa memuat penumpang sebanyak 30 orang beserta barang bawaan dan cargo maksimal 1.150 ton. LCU ini memiliki satu ramp door dan menggunakan satu outboard engine dengan tenaga $60 \mathrm{HP}$.

2. Berdasarkan hasil analisis ekonomis, LCU ini memenuhi kelayakan investasi. Berikut ini merupakan detail dari hasil analisis ekonomi:

Harga Kapal : Rp 727,333,887.07

Biaya Operasional : Rp 405,597,820/tahun

Net Present Value (NVP) : Rp207,443,553

Internal Rate of Return (IRR) : $32 \%$

Break Event Point (BEP) : Tahun ke-4

Harga Tiket : Rp 3,500 per orang

\section{B. Saran}

Saran yang dapat diberikan pada Jurnal ini antara lain:

1. Perlu dilakukan analisis sistem konstruksi dan perhitungan kekuatan dari kapal penumpang ini

2. Perlu dibuat desain halte yang layak agar kapal penumpang ini bisa beroperasi

3. Perlu dilakukan desain dengan variasi bentuk lambung lainnya untuk mengetahui desain yang paling efektif dan efisien.

\section{UCAPAN TERIMA KASIH}

Ucapan terima kasih penulis ditujukan kepada Bapak Abdul Hadi selaku Ketua RW Desa Ketingan yang memberikan bantuan data.

\section{DAFTAR PUSTAKA}

K. P. D. T. dan Transmigrasi, "Peraturan Menteri Pembangunan Daerah Tertinggal dan Transmigrasi Tentang Prioritas Pembangunan Desa," 2015. [Online]. Available: http://jdih.kemendesa.go.id/frontend/peraturan_kementerian/judul/p erubahan-atas-peraturan-menteri-desa-pembangunan-daerahtertinggal-dan-transmigrasi-nomor-21-tahun-2015-tentangpenetapan-prioritas-penggunaan-dana-desa-tahun-2016.

[2] Metrotv, "Rindu Merdeka Di Pinggir Kota," Metrotv, 2015.

[3] Infobanknews, "Fokus Program Pemerataan Pembangunan," 2016. [Online]. Available: https://www.infobanknews.com/fokuspemerataan-pembangunan-2016.

[4] K. Ginanjar, Pembangunan Untuk Rakyat. 2013.

[5] Rijkswaterstaat, Waterway Guidelines. Netherland: Ministerie van Infrastructuur en Milieu, 2011.

[6] F. Rohmadhana, "Analisis Teknis dan Ekonomis Konversi Landing Craft Tank (LCT) Menjadi Kapal Motor Penyeberangan (KMP) Tipe Ro-ro untuk Rute Ketapang (Kabupaten Banyuwangi) Gilimanuk (Kabupaten Jembrana)," POMITS, 2016. 